\title{
Anode Supported Solid Oxide Fuel Cells - Deconvolution of Degradation into Cathode and Anode Contributions
}

Hagen, Anke; Liu, Yi-Lin; Barfod, Rasmus; Hendriksen, Peter Vang

Published in:

E C S Transactions

Link to article, DOI:

$10.1149 / 1.2729105$

Publication date:

2007

Document Version

Publisher's PDF, also known as Version of record

Link back to DTU Orbit

Citation (APA):

Hagen, A., Liu, Y-L., Barfod, R., \& Hendriksen, P. V. (2007). Anode Supported Solid Oxide Fuel Cells Deconvolution of Degradation into Cathode and Anode Contributions. E C S Transactions, 7(1), 301-309. https://doi.org/10.1149/1.2729105

\section{General rights}

Copyright and moral rights for the publications made accessible in the public portal are retained by the authors and/or other copyright owners and it is a condition of accessing publications that users recognise and abide by the legal requirements associated with these rights.

- Users may download and print one copy of any publication from the public portal for the purpose of private study or research.

- You may not further distribute the material or use it for any profit-making activity or commercial gain

- You may freely distribute the URL identifying the publication in the public portal 


\title{
Anode Supported Solid Oxide Fuel Cells - Deconvolution of Degradation into Cathode and Anode Contributions
}

\author{
A. Hagen ${ }^{\mathrm{a}}$, Y.L. Liu ${ }^{\mathrm{a}}$, R. Barfod ${ }^{\mathrm{b}}$, and P.V. Hendriksen ${ }^{\mathrm{a}}$ \\ ${ }^{a}$ Fuel Cells and Solid State Chemistry Department, Risoe National Laboratory, \\ DK-4000 Roskilde, Denmark \\ ${ }^{\mathrm{b}}$ Topsoe Fuel Cell A/S, DK-2800 Lyngby, Denmark
}

The degradation of anode supported cells was studied over $1500 \mathrm{~h}$ as function of cell polarization either in air or oxygen on the cathode. Based on impedance analysis, contributions of anode and cathode to the increase of total resistance were assigned. Accordingly, the degradation rates of the cathode were strongly dependent on the $\mathrm{pO}_{2}$; they were significantly smaller when testing in oxygen compared to air. Microstructural analysis of the cathode/electrolyte interface of a not-tested reference cell carried out after removal of the cathode showed sharp craters on the electrolyte surface where the LSM particles had been located. After testing in air, these craters flattened out and decreased in size, indicating the decrease of three phase boundary length. In contrast, they remained almost unchanged after testing in oxygen giving an explanation for the observed smaller - mainly anode related degradation rate.

\section{Introduction}

Evaluation of the stability and understanding of the degradation mechanisms of technological solid oxide fuel cells (SOFCs) have been challenges, both for industries and academia. Apart from total degradation as a function of operating parameters, it is desirable to identify contributions from the individual cell components and the corresponding microstructural changes in order to be able to improve the stability of cells by focused materials and process development.

The degradation rate of anode supported SOFCs is known to be a function of the testing temperature, current density, and polarization. Cathode degradation was identified to be the dominant contribution to degradation at low temperatures and high current densities (1). A significant difference in cathode degradation has been reported for cells when tested at $750^{\circ} \mathrm{C}$ in oxygen or in air (2).

The focus of the present contribution is to identify degradation mechanisms of anode supported SOFCs. A number of nominally identical cells were tested at $750^{\circ} \mathrm{C}$ over periods of 1500 hours under different cathode atmospheres and current loads. Microstructural analysis in combination with detailed characterization by impedance spectroscopy is expected to contribute to a better understanding of the underlying degradation mechanisms, at the cathode/electrolyte interface in particular. 


\section{Experimental}

Solid Oxide Fuel Cell (SOFC). Anode supported SOFCs were studied. The supporting and active anode was a Ni-YSZ cermet, the electrolyte YSZ, and the cathode a LSM-YSZ composite. The active area was $4 \times 4 \mathrm{~cm}^{2}$. The cells studied here were produced according to the same procedure as in (3).

Test Equipment. The tests were performed using alumina test-houses with gold and nickel foil current collectors at the cathode and anode side, respectively. LSM and $\mathrm{NiO} / Y S Z$ gas distribution components were used at the cathode and anode side, respectively. Sealing was accomplished using standard glass ceramics composite seals (4). The test set-up and method are described in detail in (5). The cells were first heated in air to $1000^{\circ} \mathrm{C}$ with a heating rate of $1^{\circ} \mathrm{C} / \mathrm{min}$ and an additional weight of $8 \mathrm{~kg}$ was applied to achieve sealing. Subsequently, the anode was reduced at this temperature in diluted $(9 \%$ in nitrogen) followed by pure hydrogen, both humidified at room temperature.

Electrochemical Characterization. Prior to and after completion of the long-term test, the cell characteristics ( $i-V$ curves and impedance spectra: Solartron SI 1260 impedance analyzer) were recorded at 750 and $850^{\circ} \mathrm{C}$. Air was used as cathode gas and hydrogen with 4 or $20 \%$ humidification was applied on the anode side.

Long-Term Test. The temperature was $750^{\circ} \mathrm{C}$ and the current loads 0.75 or 1.19 $\mathrm{A} / \mathrm{cm}^{2}$. The fuel gas was a mixture of $\mathrm{CO}_{2}$ and hydrogen with a ratio of 1 to 4 , yielding an equilibrium mixture of $\mathrm{CO}, \mathrm{H}_{2}$, and $\mathrm{H}_{2} \mathrm{O}$ corresponding to the product of methane reforming with a steam to carbon ratio of two. The fuel utilization was adjusted to lie between 75 and $85 \%$ and controlled by measuring the oxygen partial pressures at the fuel outlet. Compressed air, a mixture of nitrogen and oxygen or $100 \%$ oxygen were used as cathode gasses.

Microstructural Analysis. The microstructure analysis was focused on the cathode/electrolyte interface using a FEG-SEM Supra-35 (sample not coated, accelerating voltage $2 \mathrm{kV}$, inlens secondary detector). The cathode layer was removed by treatment of the cell in concentrated hydrochloric acid $(\mathrm{HCl})$ in an ultrasonic bath at room temperature for 10 minutes. Subsequently, the sample was cleaned in water and ethanol. YSZ and (potentially formed) $\mathrm{La}_{2} \mathrm{Zr}_{2} \mathrm{O}_{7}$ (LZO) are stable in $\mathrm{HCl}$ whereas LSM is dissolved. To identify possible reaction products in the interface region, various EDS techniques (point analysis and line scan) with high or low accelerating voltage were used.

\section{Results and Discussion}

\section{$\underline{\text { Long-Term Stability in Air and Oxygen }}$}

The cells were characterized by impedance spectroscopy prior to long-term testing. Previously, a model was established assigning resistance contributions to cathode and anode processes based on detailed impedance studies $(6,7)$. According to this model, cathode processes are reflected in a high and a low frequency arc $(\sim 12000$ (HF) and $\sim 150$ (LF) $\mathrm{Hz}$ at $750^{\circ} \mathrm{C}$, respectively), whereas anode contributions appear in between these two at around 1500-3000 Hz. In addition there is a low frequency term from the anode due to conversion and diffusion (7). In Tab. 1, the resistance contributions obtained for 
two of the cells before long-term test are summarized. It can be seen that the performances, expressed as serial and polarization resistances from anode and cathode were the same.

Table I. Resistance contributions derived from impedance spectra recorded at $750^{\circ} \mathrm{C}$ before test

\begin{tabular}{|c|c|c|c|c|}
\hline To be tested in & $R s\left(\Omega \mathrm{cm}^{2}\right)$ & $\begin{array}{c}R p(\text { anode }) \\
\left(\Omega \mathrm{cm}^{2}\right)\end{array}$ & $\begin{array}{c}R p(\text { cathode-HF }) \\
\left(\Omega \mathrm{cm}^{2}\right)\end{array}$ & $\begin{array}{c}R p(\text { cathode-LF }) \\
\left(\Omega \mathrm{cm}^{2}\right)\end{array}$ \\
\hline $\mathrm{O}_{2}\left(0.75 \mathrm{~A} / \mathrm{cm}^{2}\right)$ & 0.10 & 0.15 & 0.10 & 0.12 \\
\hline $\operatorname{Air}\left(0.75 \mathrm{~A} / \mathrm{cm}^{2}\right)$ & 0.12 & 0.15 & 0.10 & 0.11 \\
\hline
\end{tabular}

Three long-term tests were performed at $750{ }^{\circ} \mathrm{C}$, in air or oxygen on the cathode side. The current loads were $0.75 \mathrm{~A} / \mathrm{cm}^{2}$ for two tests in air or oxygen and $1.19 \mathrm{~A} / \mathrm{cm}^{2}$ for one test in oxygen. The high current load in the test in oxygen was chosen in order to achieve the same initial cell voltage/cell polarization as for the test in air (see Fig, 1 and Tab. II). It must be mentioned, that the applied testing conditions were very severe and harsher than most technologically relevant conditions. This approach was taken because the SOFCs did not show significant degradation under milder - technologically more relevant - conditions, whereas the aim of this study required a large degradation effect.

The degradation behaviours in air and oxygen at $0.75 \mathrm{~A} / \mathrm{cm}^{2}$ were remarkably different (see Fig. 1). The cell voltage decreased continuously in the test in air, whereas it dropped fast initially during the test in oxygen at the same current load and remained nearly constant afterwards over the whole period of 1500 hours. Evidently, a pronounced degradation mechanism occurring in air does not occur in oxygen.

In order to assess the mechanism behind the degradation it might be important to establish whether the observed difference was a consequence of the different cell (and thus cathode) polarization or the different oxygen activity. A current density of 1.19 $\mathrm{A} / \mathrm{cm}^{2}$ was therefore applied in a test with pure oxygen to investigate the effect of high cathode polarization under the conditions of high oxygen activity in the cathode/electrolyte interface region / the absence of oxygen concentration gradients on the degradation behavior (see Fig. 1).

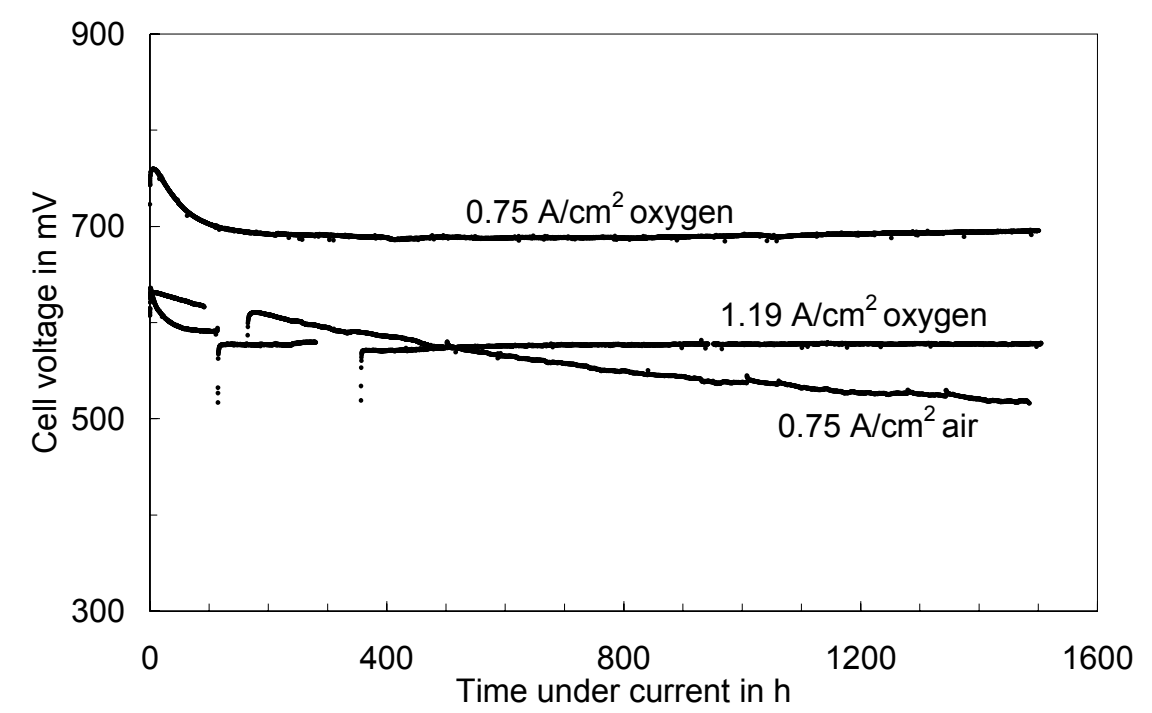

Figure 1. Cell voltage vs. time under current for tests in air or oxygen at $750{ }^{\circ} \mathrm{C}$ and 0.75 or $1.19 \mathrm{~A} / \mathrm{cm}^{2}$ 
The cell polarization $\left(\eta_{\text {cell }}=\mathrm{emf}-\mathrm{U}\right)$ is listed in Tab. II. The total cell polarization of the cell tested in oxygen at high current load $\left(1.19 \mathrm{~A} / \mathrm{cm}^{2}\right)$ was similar to that of the cell tested in air at $0.75 \mathrm{~A} / \mathrm{cm}^{2}$. The cell voltage degradation was the same as during the test in oxygen at a lower polarization. A fast initial drop of the cell voltage was followed by a period at constant value, despite the higher cell and also cathode polarization. The improved stability in oxygen comparing the two tests at $0.75 \mathrm{~A} / \mathrm{cm}^{2}$ was thus not due to a reduced polarization. It rather seems to be related with the increased oxygen activity in the cathode/electrolyte interface or the absence of oxygen gradients.

Table II. Current load and cell polarization for the tests in compressed air and oxygen

\begin{tabular}{lcc}
\hline Test in & $\boldsymbol{I}\left(\mathbf{A} / \mathbf{c m}^{\mathbf{2}}\right)$ & $\boldsymbol{\eta}_{\text {cell }}(\mathbf{m V})$ \\
\hline Oxygen & 0.75 & 260 \\
Oxygen & 1.19 & 410 \\
Air & 0.75 & 400 \\
\hline
\end{tabular}

Other factors affecting the degradation apart from oxygen activities and polarization could be traces of humidity, which were present in compressed air $(<0.1 \%)$, but not in the oxygen used in the respective test. Therefore, another long-term test was performed using dry synthetic air (a mixture of nitrogen and oxygen in the same ratio as in air; gasses were as dry as under test in oxygen) under otherwise identical conditions $\left(750^{\circ} \mathrm{C}, 0.75 \mathrm{~A} / \mathrm{cm}^{2}\right.$, synthesis gas on the anode). In Fig. 2, the degradation in terms of increase of area specific resistance is shown for the tests in compressed air and in the nitrogen/oxygen mixture. Indeed, the degradation rate was smaller in the test with synthetically mixed air. However, the pattern, i.e. the continuous increase (in contrast to a sharp initial change followed by a constant period) was the same as observed for the test in compressed air. In addition to a possible effect of humidity in the cathode gas, also a significant degradation effect related to the oxygen activity can thus be concluded.

The cells were characterized by impedance spectroscopy after completion of the longterm test and the impedance compared to the values prior to the long-term testing (see Fig. $3)$. The serial resistance increased after test in air but remained constant after test in oxygen. The resistance contributions assigned to anode processes increased after both tests, to a slightly larger extent after test in oxygen compared to air. A significant

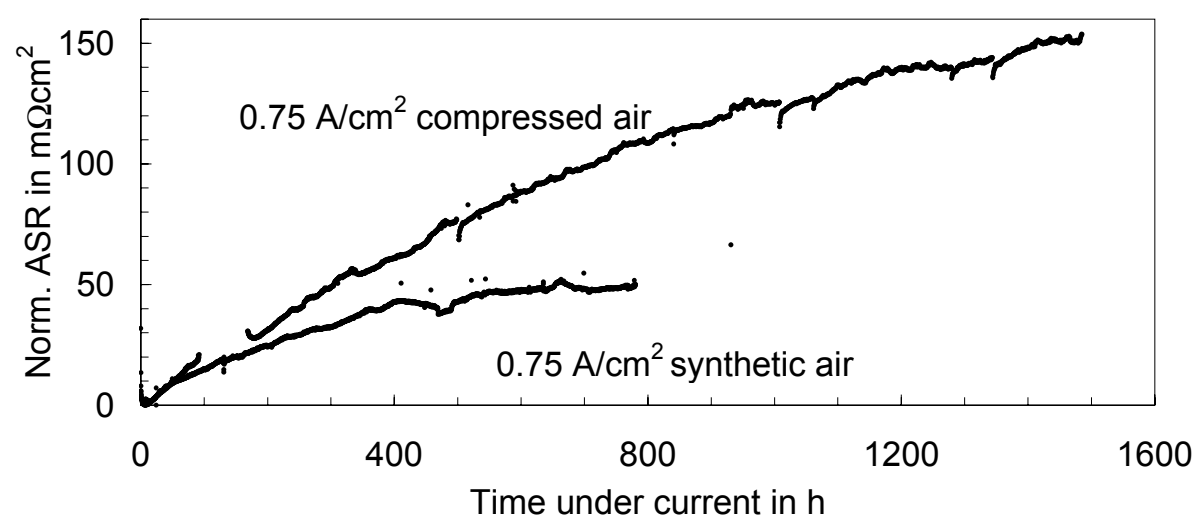

Figure 2. Normalized area specific resistance vs. time under current for tests in compressed or synthetically mixed air (oxygen and nitrogen: $1 / 5$ ) at $750^{\circ} \mathrm{C}$ and $0.75 \mathrm{~A} / \mathrm{cm}^{2}$ 
difference was observed for the cathode related resistances (both high and low frequency contributions). After test in air, the cathode resistance almost doubled, whereas it increased only slightly (by 15\%) after test in oxygen. In combination with the degradation of the cell voltage over time, these findings suggest a strong suppression of the cathode degradation when testing the cell in oxygen compared to air. Furthermore, the anode degradation could be confirmed to proceed within the first few hundred hours of long-term testing (see also Fig. 1).

Impedance analysis before and after testing can deliver valuable information about the state of the cell and those parts that were mainly affected by the test. However it is also interesting to follow resistance changes directly during uninterrupted testing by means of impedance spectroscopy under current load.

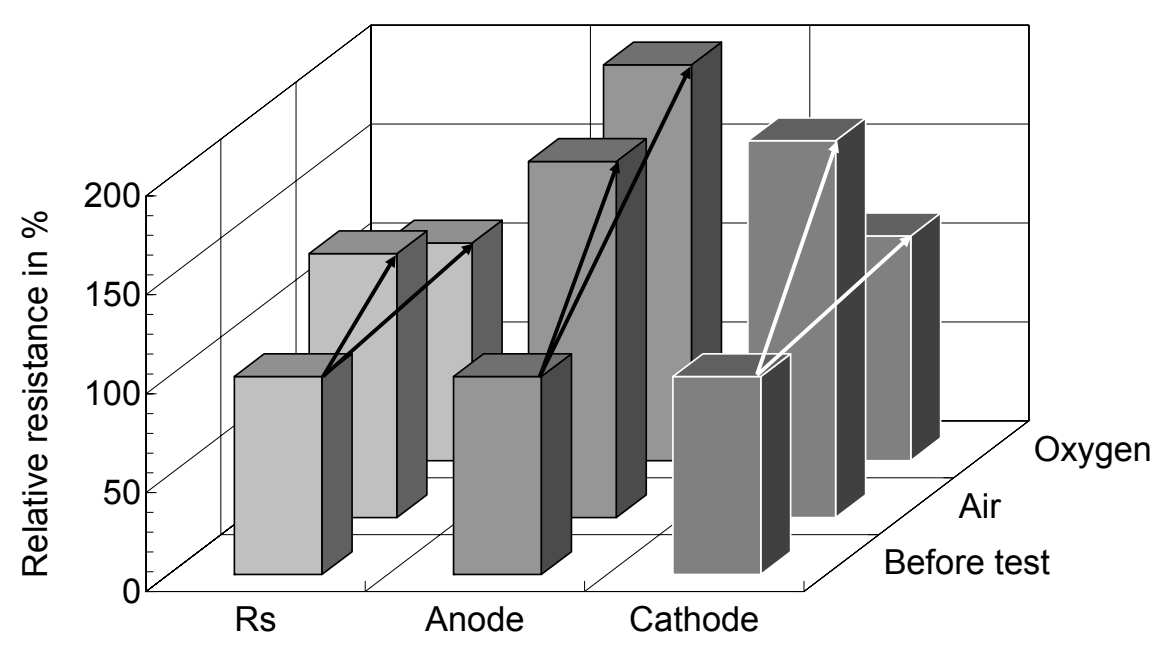

Figure 3. Relative area specific resistance contributions deduced from impedance spectra recorded at $750{ }^{\circ} \mathrm{C}$ for the cells tested in air or oxygen at $0.75 \mathrm{~A} / \mathrm{cm}^{2}$ prior to and after testing

During a number of long-term tests, impedance spectra were recorded under current load. Initially, a decrease of the resistance (activation) was observed, which has been studied widely and attributed to cathode activation processes under polarization $(8,9)$. Afterwards, the resistances increased as a consequence of degradation. In Fig. 4, impedance spectra obtained under current during tests in air or oxygen are shown after certain periods of testing.

In the impedance spectra of a test in air, the serial resistance increased continuously over the whole period, in addition, also the polarization resistance increased (see Fig. 4a). Remarkably different was the behavior in oxygen. The serial resistance remained constant over the whole 1500 hours of test. The polarization resistance increased only slightly, but fast, within the first $\sim 100$ hours under current and remained constant afterwards (see the two curves in Fig. 4b, after 100 and 1500 hours under current, which coincide). 
Consequently, the observation in the impedance spectra of the cells under OCV before and after test was completely reflected in the impedance spectra recorded under current.
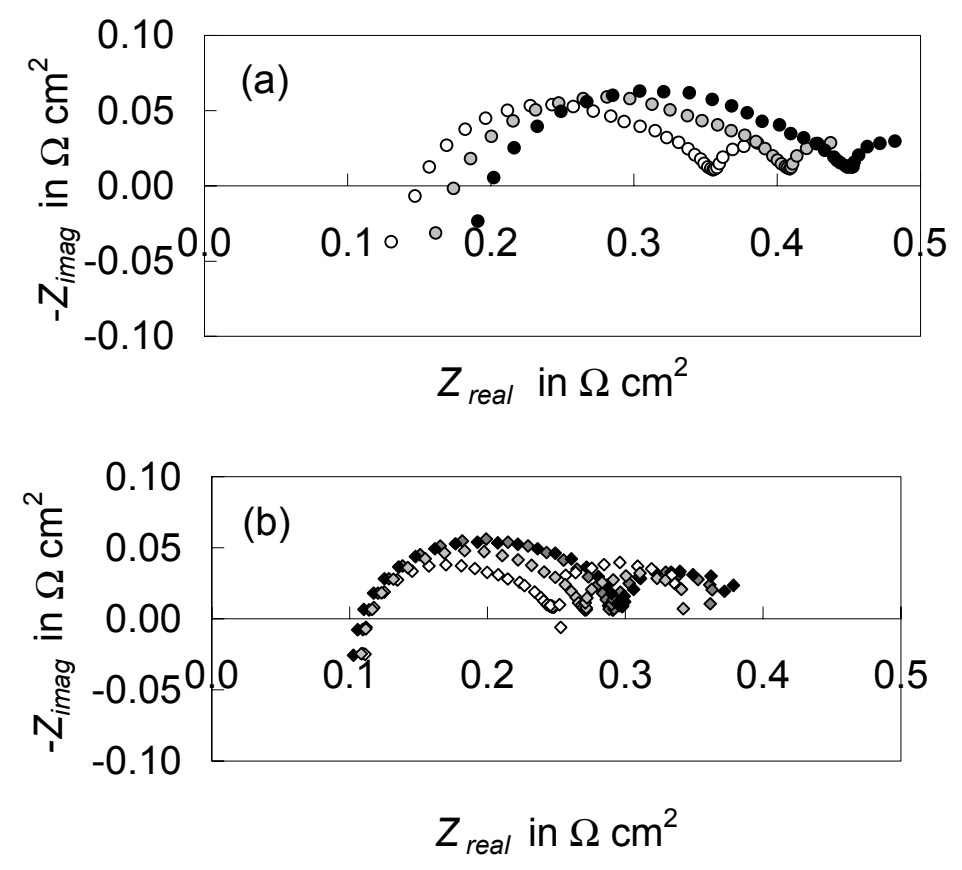

Figure 4. Impedance spectra recorded under current load at $750^{\circ} \mathrm{C}, 0.75 \mathrm{~A} / \mathrm{cm}^{2}$ (a): test in air after 12 (white), 500 (grey), and 1000 (black) hours under current and (b): test in oxygen after 13 (white), 50 (light grey), 100 (grey), and 1500 (black) hours under current

\section{$\underline{\text { Microstructural Analysis }}$}

The aim of the microstructural analysis was to relate the degradation behavior observed in air and oxygen to features on the cathode side. Therefore, the focus was set to the electrolyte/cathode interface. A convenient method to evaluate the contact area of LSM particles on the YSZ electrolyte is to remove the LSM and investigate the imprint of it left on the electrolyte surface. By etching using $\mathrm{HCl}$, only LSM but not YSZ or zirconate phases are removed. In Fig. 5, the electrolyte surfaces of a reference cell and the two cells tested in air or oxygen over 1500 hours at $750^{\circ} \mathrm{C}$ and $0.75 \mathrm{~A} / \mathrm{cm}^{2}$ are shown after etching away the cathode.

On the electrolyte of the not tested reference cell, clear craters are visible, which were contact regions of LSM particles on YSZ. Points left by YSZ appear as round protrusions. After testing in oxygen, the craters appeared still sharp, maybe even sharper. Noticeable differences in the morphology were observed on the cell after test in air.

In the cell tested in air, a flattening of the crater rings and a reduction of their size occurred and nano-size particles were found in association with the craters. The flattening of LSM crater rings and size reduction on the YSZ surface in the cell tested in air may correspond to a loss of contact between cathode (LSM) and electrolyte. In a previous 
study of the degradation as function of temperature and polarization, a loss of contact points after test at $750^{\circ} \mathrm{C}$ and high current load $\left(0.75 \mathrm{~A} / \mathrm{cm}^{2}\right)$ - the same conditions as in this contribution - was concluded from impedance analysis of the cells before and after test (1). The findings in the microstructural analysis thus seem to support the conclusions drawn previously.

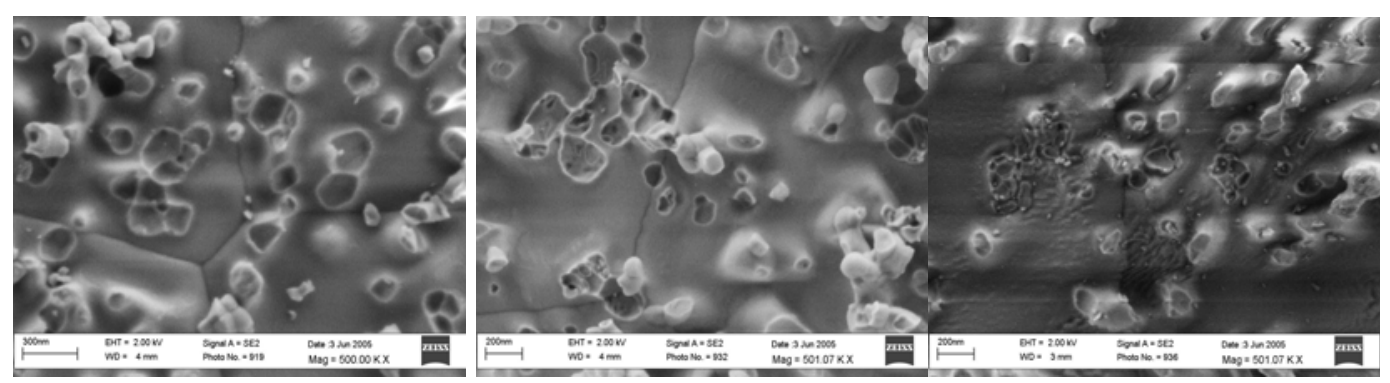

Figure 5. Electrolyte surface of cells prior to testing (left), after test in oxygen (center) or air (right) after removal of the cathode

The nano-particles, also found in the cell after test in air, may be an indication for chemical interactions between LSM and YSZ, for example the formation of lanthanum zirconate phases (LZO). They may also be impurity phases. But the chemical composition of these particles cannot be determined directly as their size was too small for quantitative analysis by SEM/EDS.

There was also a difference in the surface morphology of the electrolyte in areas surrounding LSM craters. The electrolyte surface of the cell tested in air was rougher with more pronounced wrinkles as compared with the cell tested in oxygen (Fig. 5). The area with wrinkles stretched about $200-300 \mathrm{~nm}$ to $1 \mu \mathrm{m}$ from the crater.

In the EDS analysis (see Tab. III), no Sr was detected, which was an indication for the complete removal of LSM. Focusing on the crater regions, the Si and Mn contents were higher than in the surrounding areas for all three cells. The La content was higher in two cells, the reference cell and in the cell tested in air, particularly in the latter. The Si-level was lowest in the cell tested in oxygen.

Table III. Qualitative and semi-quantitative elemental analysis by EDS

\begin{tabular}{lllllll}
\hline Element & La & & $\mathrm{Si}$ & & $\mathrm{Mn}$ \\
Location & Crater & Surroundings & Crater & Surroundings & Crater & Surroundings \\
\hline Not-tested cell & +++ & + & +++ & + & ++++ & + \\
Cell tested in oxygen & ++ & ++ & ++ & ++ & ++++ & ++ \\
Cell tested in air & +++++ & + & ++++ & ++ & +++ & ++ \\
\hline
\end{tabular}

These findings of extra $\mathrm{La}$ and $\mathrm{Si}$ in crater areas as compared to the surrounding regions are indications for the presence of secondary phases, LZO and silicate or Lasilicate. The formation of LZO has been widely studied in literature (10-12). The conductivity of LZO is 2-3 orders of magnitude lower than that of the zirconia electrolyte (14). It was discussed to lead to a degraded mechanical adhesion on the cathode/electrolyte interface (10). La-silicate was reported to form at the $\mathrm{LaMnO}_{3} / \mathrm{YSZ}$ interface during aging at $1450^{\circ} \mathrm{C}(13)$. 
Extra $\mathrm{Mn}$ in crater areas could be an indication for local dissolution of $\mathrm{Mn}$ from the LSM particles into the sintering neck of YSZ, which agrees with findings by A. Mitterdorfer and L. J. Gauckler (11) who reported Mn-doped YSZ crater rings with $\sim 7.4 \% \mathrm{Mn}$ (by EDS/TEM) after sintering at $1100^{\circ} \mathrm{C}$.

The EDS results combined with the microstructural observations suggest the occurrence of local interfacial reactions between LSM and electrolyte to form LZO during test at $750^{\circ} \mathrm{C}$ (and may be also during fabrication), in particular at lower $\mathrm{pO}_{2}$ at the cathode side (air vs. oxygen). There might be more silicate phase in the electrolyte/cathode interface region after test in air. The presence of both LZO and silicate phases reduces the electrochemical activities at the three-phase-boundary, weaken the LSM/electrolyte contact both electrically and mechanically and may account for the different degradation behaviors in air and oxygen.

\section{Summary}

The degradation behavior of anode supported SOFCs was studied as a function of the cathode atmosphere and the polarization. The total degradation can be divided in at least two main processes, one initial, rather fast (within the first few hundred hours) that mainly proceeds at the anode and a second continuous process occurring on the cathode. This latter degradation mechanism was found to be strongly dependent on the $\mathrm{pO}_{2}$; it was almost suppressed when running the test in oxygen compared to air.

This suppression also works at high total cell and cathode polarization and seems therefore to be mainly caused by the change in oxygen activity in the interface region and elimination of oxygen concentration gradients when going to oxygen atmosphere rather than being related to the reduction of cathode polarization in oxygen.

Microstructural investigations suggest that the flattening and size reduction of the crater rings and formation of secondary phases (for example LZO) in the LSM/electrolyte contact areas are most important degradation mechanisms of the cathode. In oxygen, these processes are suppressed to a large extent and therefore the cathode degradation can be diminished or even stopped. A formation of silicate phase cannot be excluded. Direct identification of these nano-sized phases requires more advanced techniques.

\section{Acknowledgments}

The authors thank O. Hansen, H. Henriksen, and S. Koch for technical assistance. The financial support by Danish Public Service Organization, project PSO-Eltra-5849 and by the European Community, IP-project REAL-SOFC (SES6-CT-2003-502612), is gratefully acknowledged.

\section{References}

1. A. Hagen, R. Barfod, P.V. Hendriksen, Yi.L. Liu, and S. Ramousse, J. Electrochem. Soc., 153(6), A1165 (2006).

2. R. Barfod, A. Hagen, S. Ramousse, and P.V. Hendriksen, in: Solid state electrochemistry. Proceedings. 26. Risø international symposium on materials science, Risø (DK), 4-8 Sep 2005, S. Linderoth, A. Smith, N. Bonanos, A. Hagen, L. 
Mikkelsen, K. Kammer Hansen, D. Lybye, P.V. Hendriksen, F.W. Poulsen, M. Mogensen, and W.G. Wang, Editors, Risø National Laboratory, Roskilde, p. 121 (2005).

3. A. Hagen, M. Menon, S. Ramousse, P.H. Larsen, R. Barfod, and P.V. Hendriksen, Fuel Cells, 2, 146 (2006).

4. J. G. Larsen, P. H. Larsen, and C. Bagger, "High Temperature Sealing Materials". US Patent Ser. no. 60/112039 pending.

5. M. Mogensen and P.V. Hendriksen in High Temperature Solid Oxide Fuel Cells, Fundamentals, Design, and Applications, S.C. Singhal, K. Kendall, Editors, Chapt. 10, Elsevier (2003).

6. R. Barfod, A. Hagen, S. Ramousse, P.V. Hendriksen, and M. Mogensen, Fuel Cells, 6(2), 141 (2006).

7. R. Barfod, M. Mogensen, T. Klemensoe, A. Hagen, Y.L. Liu, and P.V. Hendriksen, J. Electrochem. Soc., 154(4) (2007) in press.

8. X.J. Chen, K.A. Khor, and S.H. Chan, J. Power Sources, 123, 17 (2003).

9. M.J. Jørgensen, and M. Mogensen, J. Electrochem. Soc., 148, A433 (2001).

10. M.J. Heneka and E. Ivers-Tiffee, in: Solid State Electrochemistry. Proceedings. 26. Risø International Symposium on Materials Science, Risø (DK), 4-8 Sep 2005, S. Linderoth, A. Smith, N. Bonanos, A. Hagen, L. Mikkelsen, K. Kammer Hansen, D. Lybye, P.V. Hendriksen, F.W. Poulsen, M. Mogensen, and W.G. Wang, Editors, Risø National Laboratory, Roskilde, p. 215 (2005).

11. A. Mitterdorfer and L.J. Gauckler, Solid State Ionics, 111, 185 (1998).

12. C. Clausen, C. Bagger, J.B. Bilde-Sørensen and A. Horsewell, Solid State Ionics, 7071, 59 (1994).

13. D. Kuscer, J. Holc, M. Hrovat, S. Bernik, Z. Samardzija and D. Kolar, Solid State Ionics, 78, 79 (1995).

14. J.A. Labrincha, J.R. Frade and F.M.B. Marques, J. Mater. Sci. 28 (1993) 3809. 